\title{
Evaluation of the virulence potential of Yersinia enterocolitica isolates from milk by cell invasion-inhibition assay
}

\author{
Ruchi KUSHAL, Sanjeev K. ANAND* \\ Division of Dairy Microbiology, National Dairy Research Institute, Karnal-132001, India
}

Received 29 April 2005 - Accepted 10 October 2005

\begin{abstract}
The psychrotrophic nature of Yersinia enterocolitica is of particular significance in milk and milk products that are normally refrigerated for considerable duration. Different virulence markers have been suggested to differentiate the non-virulent strains from virulent ones. The previous study conducted in our lab, however, failed to show any consistent correlation amongst these markers. As the process of invasiveness of the strain comprises attachment to the intestinal epithelial cell surface, leading to colonization, cell damage, internalization, disturbance of regulatory cell mechanisms and intracellular proliferation, an attempt was made in the present study to evaluate the virulence potential of Yersinia enterocolitica isolates from milk by cell invasion-inhibition assay. The present study revealed the presence of $Y$. enterocolitica in about $32.7 \%$ of the raw milk samples. Out of a total of about 36 confirmed isolates, only one isolate was found to be virulent based on the cell invasion-inhibition assay.
\end{abstract}

milk / Yersinia / virulence / cell invasion-inhibition assay

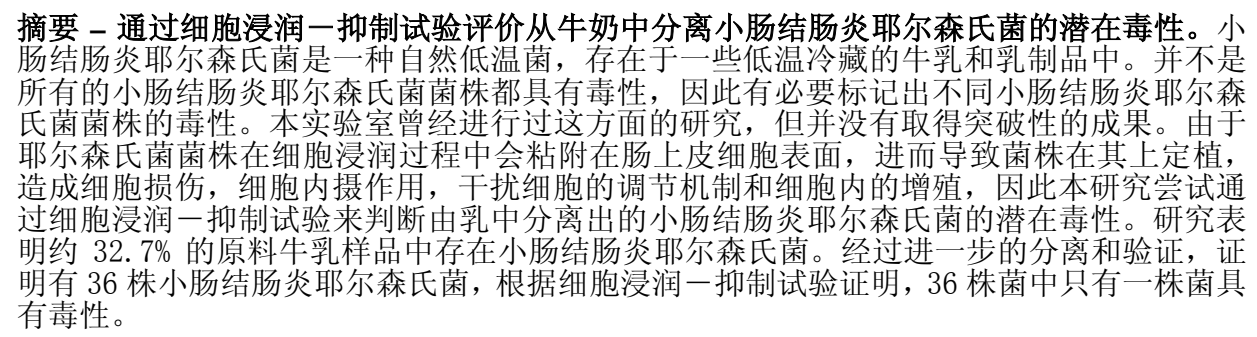

\section{耶尔森氏菌 / 毒性}

Résumé - Évaluation du potentiel de virulence de souches d'Yersinia enterocolitica isolées de lait par un test d'invasion-inhibition cellulaire. La nature psychrotrophe d'Yersinia enterocolitica a une importance particulière dans le lait et les produits laitiers qui sont normalement conservés longtemps au froid. Différents marqueurs de virulence ont été proposés pour différencier les souches non virulentes des souches virulentes. L'étude antérieure réalisée dans notre laboratoire n'avait cependant pu démontrer aucune bonne corrélation entre ces marqueurs. Comme le processus

\footnotetext{
* Corresponding author (通讯作者): anand_sanjeevk@yahoo.co.uk
} 
d'invasion de la souche comporte l'adhésion à la surface des cellules épithéliales de l'intestin conduisant à la colonisation, à la lésion de la cellule, à l'internalisation, à la perturbation des mécanismes régulateurs de la cellule et à la prolifération intracellulaire, un essai a été mis en place dans la présente étude pour évaluer le potentiel de virulence d'isolats d'Yersinia enterocolitica provenant de lait par un test d'invasion-inhibition cellulaire. Les résultats révèlent la présence d'Yersinia enterocolitica dans environ $32,7 \%$ des échantillons de lait cru. Sur un total de 36 isolats confirmés, un seul s'avérait être virulent.

lait / Yersinia / virulence / test d'invasion-inhibition cellulaire

\section{INTRODUCTION}

Yersinia enterocolitica, the cause of yersiniosis, is widely distributed in the environment. It is one of the few human pathogens that can grow at refrigeration temperatures and its presence in food is of great public health concern. The psychrotrophic nature of the microorganism is of particular significance in milk and milk products that are normally refrigerated for considerable duration $[1,4,7,15,17,20]$. Of greater consequence is the evaluation of the virulence of strains [5,23], since it is the virulent strains, though encountered infrequently, that may cause food-borne illness. On the other hand, most of the incidental Yersinia could be non-invasive and may be present in food products without causing any ill effects. These strains are sometimes also referred to as environmental strains.

A number of schemes have been proposed to categorize the strains into at least five biotypes [16]. Some of these biotypes have now been accorded a species status. Reference has often been made to biotype 1 , that has recently been divided into $1 \mathrm{~A}$, representing the strains of environmental origin that are non-pathogenic, and $1 \mathrm{~B}$, that are of human origin and are pathogenic. In view of the importance of the virulence status of the strains, different virulence markers such as colony morphology on trypticase soya agar, crystal violet binding, congo red uptake, calcium-dependent growth and auto-agglutination reaction have been suggested to differentiate non-virulent strains from virulent ones. The previous study conducted in our lab, however, failed to show any consistent correlation amongst these markers [8]. Some other authors have reported on the virulence of Yersinia strains in HeLa cells [18, 19] and human epithelial (HEP 2) cells [10]. Similarly, the use of human intestinal cell lines such as Caco-2 and Colo-320 has also been reported for studying the invasion of enterovirulent strains of $Y$. pseudotuberculosis [3] and cytotoxicity of selected species [21]. As the process of invasiveness of the strain comprises attachment to the intestinal epithelial cell surface, leading to colonization, cell damage, internalization, disturbance of regulatory cell mechanisms and intracellular proliferation, an attempt was made in the present study to evaluate the virulence potential of $Y$. enterocolitica isolates from milk by cell invasion-inhibition assay.

\section{MATERIALS AND METHODS}

\subsection{Isolation of Yersinia enterocolitica from milk samples}

A total of 110 samples was screened for the presence of Yersinia enterocolitica. These consisted of 80 raw milk and 30 pasteurized milk samples. In order to have a wider coverage, the samples were drawn from various villages and mostly belonged to single animal holdings. The organism was isolated using the standard procedure involving a primary enrichment step by taking $25 \mathrm{~mL}$ of well mixed sample in $225 \mathrm{~mL}$ of peptone-sorbitol-bile broth (PSBB) and incubating it at $10^{\circ} \mathrm{C}$ for $10 \mathrm{~d}$, followed by alkali treatment $(0.5 \% \mathrm{KOH}$ in $0.5 \%$ saline $)$, and subsequent streaking on cefsulodinirgasan-novobiocin (CIN) agar plates. The incubation was carried out for $48 \mathrm{~h}$ at $25^{\circ} \mathrm{C}$ and the typical colonies with a deep red center (Bull's eye) with a sharp border surrounded by a clear, colorless zone with an 
entire edge were selected and further identified biochemically for the $\mathrm{H}_{2} \mathrm{~S}$ production, urease test, esculin hydrolysis, lipase test, oxidase test, catalase test and Gram staining [13].

\subsection{Adherence assay}

The adherence of the representative isolates was observed using light and scanning electron microscopy (SEM), while the quantitative estimation was carried out by cell invasion-inhibition assay.

For adherence studies, Colo-320 DM monolayers were prepared on glass coverslips that were placed in six well tissue culture plates in $\mathrm{CO}_{2}$ incubator. The monolayers were washed twice with phosphate buffered saline (PBS). A 100- $\mu \mathrm{L}$ sample of the selected isolate was cultured in brainheart-infusion (BHI) broth for $24 \mathrm{~h}$ at $25^{\circ} \mathrm{C}$ and was added to each coverslip with a monolayer of cell line. The tissue culture plates with coverslips were incubated at $37{ }^{\circ} \mathrm{C}$ in $10 \% \mathrm{CO}_{2}: 90 \%$ air atmosphere. After one hour of incubation, the monolayers were washed five times with PBS and fixed with methanol. For light microscopy different staining techniques were followed using Gram stain, Giemsa and light green.

For SEM studies, the tissue culture cells were grown on glass chips $\left(1 \mathrm{~cm}^{2}\right)$. After the bacterial adhesion assay, as adopted for light microscopy, the cells were fixed for $2 \mathrm{~h}$ at $4{ }^{\circ} \mathrm{C}$ with $2.5 \%$ gluteraldehyde in $0.1 \mathrm{~mol} \cdot \mathrm{L}^{-1}$ phosphate buffer $(\mathrm{pH} 7.4)$. After two washes with phosphate buffer, the cells were post-fixed for $1 \mathrm{~h}$ with $2 \%$ osmium tetra oxide $\left(\mathrm{OsO}_{4}\right)$ in the same buffer. They were then washed three times with phosphate buffer and dehydrated in graded series of ethanol $(30,50,70,60,90$ and $100 \%$ ). The cells were dried by freezedrying and were coated with gold. The specimens were then examined with a Hitachi S-405 scanning electron microscope.

\subsection{Pathogen cell invasion- inhibition assay}

Bacterial internalization was determined by estimation of bacteria located within the cells of the Colo-320 DM cell line using a reference strain of Yersinia enterocolitica (MTCC-861, obtained from IMTECH, Chandigarh, India) and the milk isolates. To carry out the invasion-inhibition assay, the Colo-320 DM cell lines were grown on six well tissue culture plates in RPMI-1640 medium supplemented with $10 \%$ fetal calf serum. Healthy cells, as observed by the inverted microscope, were taken for further studies. The Colo-320 DM monolayers were washed twice with phosphate buffer saline (PBS) before the assay. About 2.0$\mathrm{mL}$ suspensions of 24-h-old BHI growth of the Yersinia cultures, obtained at $25^{\circ} \mathrm{C}$, were added to wells of tissue culture plates. The plates were incubated for $2 \mathrm{~h}$ at $37{ }^{\circ} \mathrm{C}$ in $10 \% \mathrm{CO}_{2}: 90$ percent air atmosphere. After incubation, the plates were washed five times with sterile PBS and then incubated for $60 \mathrm{~min}$ in a medium containing $100 \mu \mathrm{g}$ of gentamycin $\cdot \mathrm{mL}^{-1}$. Since the gentamycin does not diffuse rapidly into the cells, the bacteria that adhered to the brush borders of Colo-320 DM were rapidly killed. Contrary to this, the bacteria located within the cells of the cell line were not killed. The monolayers were then washed with PBS and lysed with sterilized water. Appropriate dilutions were plated on cefsulodin-irgasan-novobiocin (CIN) agar plates and incubated for $48 \mathrm{~h}$ at $25^{\circ} \mathrm{C}$ to determine the number of viable intracellular yersiniae. Each assay was conducted in duplicate with two successive passages of Colo-320 DM cells [2].

\section{RESULTS AND DISCUSSION}

\subsection{Yersinia enterocolitica milk-borne isolates}

The results obtained in the present study indicated the presumptive presence of $Y$. enterocolitica in about $73 \%$ of the samples of raw milk. On the other hand, none of the pasteurized milk samples were found to contain the organism.

Of the 69 isolates, selected on the basis of colony morphology, only 58 were identified as presumptive $Y$. enterocolitica based on the biochemical identification 


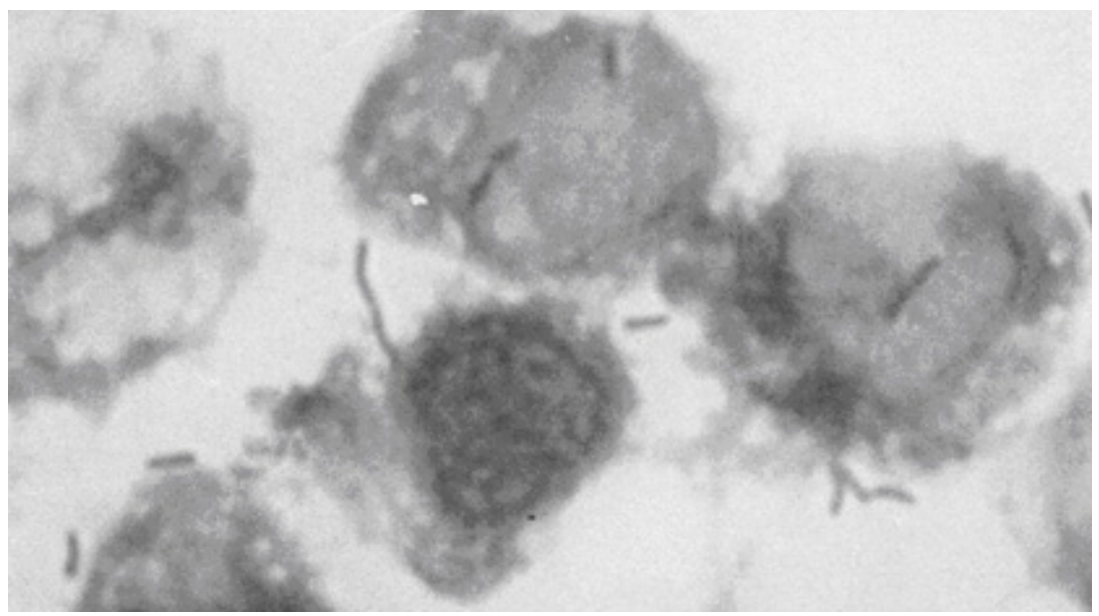

Figure 1. Adhesion of a virulent isolate to Colo-320 DM cells (Giemsa stain, 1000x).

scheme as described above. Similar tests have also been used by other authors for presumptive testing of samples [22].

The presumptive identification of the isolates was followed by the primary characterization and confirmation tests as per Bergey's Manual [6]. On the basis of these tests about 47 isolates were primarily identified as $Y$. enterocolitica, which were oxidase-negative and catalase-positive. On the other hand, on the basis of additional tests [6], such as the negative decarboxylase test for lysine and arginine, inability to deaminate phenylalanine, motility at $25^{\circ} \mathrm{C}$, indole production, a negative response to citrate utilization and the Voges-Proskauer test (at $37^{\circ} \mathrm{C}$ ), and a negative or delayed positive for the indole test, only 36 isolates were finally identified as confirmed Yersinia enterocolitica isolates. On the basis of the final distribution pattern of these confirmed isolates, it was concluded from the present study that about $32.7 \%$ of the raw milk samples were positive for Yersinia enterocolitica. There have also been several worldwide reports in the past regarding the incidence of the organism in raw milk that has varied from $13.1 \%$ in Sweden to $48.1 \%$ in Wisconsin. On the other hand, its reported presence in pasteurized milk has mainly been due to either inadequate heattreatment or post-pasteurization contami- nation $[1,4,7,15,17,20]$. Our results also confirmed the adequacy of HTST pasteurization in completely eliminating the organism.

\subsection{Adhesion and invasive studies}

Experiments conducted to establish the infective capacity, using in vitro studies with monolayers of Colo-320 DM cell lines, revealed the potential of the virulent isolates to adhere to human cell lines (Fig. 1). It may be seen that the organisms adhered to the periphery of the cell line, as shown by Giemsa stain, under light microscopy. However, neither Gram or light green stains could achieve the desired results. Our results support the previous report on adherence using light microscopy [9].

In the case of studies using scanning electron microscopy, the interaction of the organism and the surface of cultured cell lines could further substantiate the results on infectivity of the virulent isolates (Fig. 2). As the intestinal epithelial cells act as the first barrier to bacteria, the attachment of pathogenic bacteria to the intestinal epithelial cell-surfaces was reported to be significant for colonization, cell damage, internalization and disturbances of regulatory cell mechanisms [3]. The attachment to 


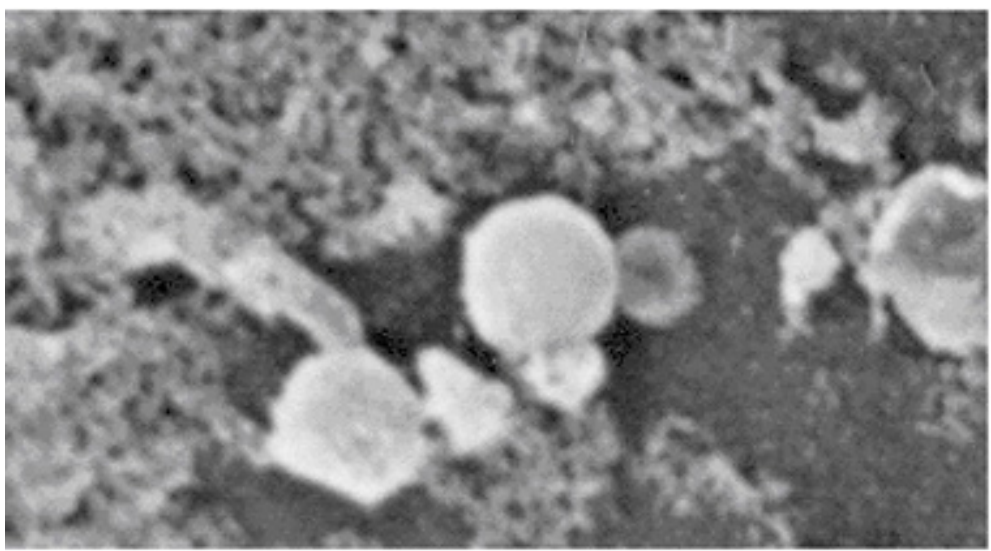

Figure 2. Scanning micrograph showing the penetration of a virulent isolate into the peripheral region of Colo-320 DM cells $(6000 \times)$.

Table I. Invasion efficiency (IE\%) of Colo-320 DM cell monolayers by virulent strains of Yersinia enterocolitica.

\begin{tabular}{lccc}
\hline & \multicolumn{3}{c}{ Multiplicity of infection $\left(\mathrm{cfu} \cdot \mathrm{mL}^{-1}\right)$} \\
\cline { 2 - 4 } Strains & Inoculated & $\begin{array}{c}\text { After Gentamycin } \\
\text { Treatment }\end{array}$ & IE\% \\
\hline Y. enterocolitica & $4 \times 10^{2}$ & 3 & 0.75 \\
(MTCC 861) & $5 \times 10^{2}$ & 4 & 0.80 \\
Y. enterocolitica & $4 \times 10^{2}$ & 2 & 0.50 \\
(Raw milk isolate) & $6 \times 10^{2}$ & 2 & 0.33 \\
\hline
\end{tabular}

the intestinal walls and penetration of the mucosa was also suggested to facilitate the survival and proliferation of the organism in the host tissue $[11,12]$.

\subsection{Cell invasion-inhibition assay}

The infectivity was also shown directly by plating techniques using a cell invasioninhibition assay. The data presented in Table I reveals the invasion efficiency (IE\%) of the virulent isolate from raw milk was $0.5 \%$, as compared with 0.8 for the reference strain (MTCC 861). The present investigation also revealed that at least one raw milk isolate amongst the 36 confirmed isolates of Yersinia enterocolitica showed virulence potential by cell invasion-inhibi- tion assay. A similar IE\% was previously also used as an index of infectivity for Listeria monocytogenes [14].

\section{CONCLUSION}

The present study reveals the presence of $Y$. enterocolitica in about $32.7 \%$ of the raw milk samples. Out of a total of about 36 confirmed isolates, only one isolate was found to be virulent based on the cell invasioninhibition assay. The study thus emphasizes the importance of establishing the infective properties of the Yersinia enterocolitica isolates with techniques such as tissue culturing, prior to formulating a further action plan for its control. 
Acknowledgements: The financial assistance provided to the first author in the form of a NDRI Jr. Research Fellowship is gratefully acknowledged by the first author.

\section{REFERENCES}

[1] Ados R.T., Franco-Bdg-de M., Landgraf M., Incidence of Yersinia species in food in Sao Paulo, Brazil, Int. J. Food Microbiol. 21 (1994) 263-270.

[2] Bernet M.F., Brassart D., Neeser J.R., Servin A.L., Adhesion of human bifidobacterial strains to cultured human intestinal epithelial cells and inhibition of enteropathogens-cell interaction, Appl. Environ. Microbiol. 59 (1993) 4121-4128.

[3] Coconnier M.H., Bernet M.F., Kerneis S., Chauvière G., Fourniat J., Servin A.L., Inhibition of adhesion of enteroinvasive pathogens to human intestinal Caco- 2 cells by Lactobacillus acidophilus strain LB decreases bacterial invasion, FEMS Microbiol. Lett. 110 (1993) 299-305.

[4] Errico M.M., Pavia M., Prospero E., Grasso G.M., Angelill I.F., Yersinia sp. Isolation from raw milk and cheese in Compania, Italy, Ig. Mod. 94 (1990) 212-220.

[5] Greenwood M.H., Hooper W.L., Excretion of Yersinia sp. associated with consumption of pasteurized milk, Epidemiol. Infect. 104 (1990) 345-350.

[6] Holt J.G., Krieg N.R., Staley J.T., William S.T., Bergey's Manual of Determinative Microbiology, 9th edn., Williams and Wilkins, Baltimore, USA, 1994.

[7] Huges D., Isolation of Yersinia enterocolitica from milk and a dairy farm in Australia, J. Appl. Microbiol. 46 (1979) 125-130.

[8] Kushal R., Anand S.K., A comparison of different virulence markers of Yersinia enterocolitica, J. Food Sci. Technol. 38 (2001) 256528.

[9] Le Chevallier M.W. Schiemann D.A., Macfeters G.A., Factors contributing to the reduced invasiveness of chlorine injured $\mathrm{Yer}$ sinia enterocolitica, Appl. Environ. Microbiol. 53 (1987) 1358-1364.

[10] Maki M., Gronroos P., Wesikari T., Visakorpi J.K., The invasiveness of Yersinia enterocolitica in acute diarrhea, Acta Paediatr. Belg. 31 (1978) 108-109.

[11] Mantle M., Husar S.D., Adhesion of Yersinia enterocolitica to purified, rabbit and human intestinal mucin, Infect. Immun. 61 (1993) 2340-2346.
[12] Mantle M., Husar S.D., Binding of Yersinia enterocolitica to purified, native small intestinal mucins from rabbits and human involves interaction with mucin carbohydrate moiety, Infect. Immun. 62 (1994) 12191227.

[13] Marshall R.T., Standard Methods for the Examination of Dairy Products, American Public Health Association, Washington DC, USA, 16th edn., 1993, pp.159-164.

[14] Meyer D.H., Bunduki M., Beliveau C.M., Donnelly C.W., Diffrences in invasion and adherence of L. monocytogenes with mammalian gut cells, Food Microbiol. 9 (1992) 115-126.

[15] Moustafa M.K., Ahmed A.A.H., Marth E.H., Behavior of virulent Yersinia enterocolitica during manufacture and storage of Colbytype cheese, J. Food Prot. 46 (1983) 318320.

[16] Nilehn B., Studies on $Y$. enterocolitica with special reference to bacterial diagnosis and occurrence in human acute enteric disease, Acta Pathol. Microbiol. Scand. (Suppl.) 206 (1969) 1-48.

[17] Norberg P., Yersinia in pasteurized milk, Var-Foeda 33 (1981) 454-451.

[18] Pederson K.B., Winblad S., Studies on Yersinia enterocolitica isolated from swine and dogs, Acta Pathol. Microbiol. Scand. B 87 (1979) 137-140.

[19] Sai T., Nagata K., Kokaa H., A study on the pathogenicity of Yersinia enterocolitica, Jap. J. Bacteriol. 30 (1975) 116.

[20] Schiemann D.A., Association of Yersinia enterocolitica with the manufacture of cheese and occurrence in pasteurized milk, Appl. Environ. Microbiol. 36 (1978) 274277.

[21] Smit H.F., Woerdenbag H.J., Singh R.H., Meulenbeld G.J., Labedie R.P., Zwaving J.H., Ayurvedic herbal drugs with possible cytotoxic activity, J. Ethnopharmacol. 47 (1995) 75-84.

[22] Tibana A., Warnken M.B., Nunes M.P., Ricciardi I.D., Noleto A.L.S., Occurrence of Yersinia species in raw and pasteurized milk in Rio de Janeiro, Brazil, J. Food Prot. 50 (1987) 580-583.

[23] Walker S.J., Gilmour A.J., A comparison of media and methods for the recovery of Yersinia enterocolitica and Yersinia enterocolitica like bacteria from milk containing simulated raw milk microflora, Appl. Bacteriol. 60 (1986) 175-183. 